\title{
Taking Implementation Seriously in the Evaluation of Urban Growth Management Strategies: "Safeguarding the Future" of the Antwerp City-Region
}

\author{
Clemens de Olde * ${ }^{*}$ and Stijn Oosterlynck
}

Department of Sociology, Faculty of Social Sciences, University of Antwerp, Stadscampus-Building M, St-Jacobstraat 2, 2000 Antwerp, Belgium; stijn.oosterlynck@uantwerpen.be

* Correspondence: clemens.deolde@uantwerpen.be; Tel.: +32-32655344

check for updates

Citation: de Olde, C.; Oosterlynck, S. Taking Implementation Seriously in the Evaluation of Urban Growth Management Strategies: "Safeguarding the Future" of the Antwerp City-Region. Land 2021, 10, 159. https://doi.org/10.3390/land 10020159

Academic Editor: Fabrizio Battisti Received: 29 December 2020

Accepted: 29 January 2021

Published: 5 February 2021

Publisher's Note: MDPI stays neutral with regard to jurisdictional claims in published maps and institutional affiliations.

Copyright: (c) 2021 by the authors. Licensee MDPI, Basel, Switzerland. This article is an open access article distributed under the terms and conditions of the Creative Commons Attribution (CC BY) license (https:// creativecommons.org/licenses/by/ $4.0 /)$.

\begin{abstract}
Contemporary evaluations of urban growth management (UGM) strategies often take the shape of quantitative measurements of land values and housing prices. In this paper, we argue that it is of key importance that these evaluations also analyse the policy formulation and implementation phases of growth management strategies. It is in these phases that the institutions and discourses are (trans)formed in which UGM strategies are embedded. This will enable us to better understand the conditions for growth management policies' success or failure. We illustrate this point empirically with the case of demarcating urban areas in the region of Flanders, Belgium. Using the Policy Arrangement Approach, the institutional dynamics and discursive meanings in this growth instrument's formulation and implementation phase are unravelled. More specifically, we explain how the Flemish strategic spatial planning vision of restraining sprawl was transformed into one of accommodating growth in the demarcation of the Antwerp Metropolitan Area, epitomised by two different meanings of the phrase "safeguarding the future." In conclusion, we argue that, in Antwerp, the demarcation never solidified into a stable policy arrangement, rendering it largely ineffective. We end by formulating three recommendations to contribute to future attempts at managing urban growth in Flanders.
\end{abstract}

Keywords: urban growth management; urban sprawl; land use planning; zoning; strategic spatial planning; institutionalism; discourse; Antwerp; Flanders

\section{Introduction: Evaluating Growth Management}

Compact settlements are beneficial in terms of the cost of mobility and providing public services as well as safeguarding valuable agricultural land and nature. Therefore, planning strategies have been developed throughout the twentieth century in order to guide growth and protect open space [1]. Urban growth boundaries are arguably the most famous instrument used in these growth management strategies. Early examples are found as Greenbelts in the United Kingdom and, from the 1950s, as statutory lines around cities in the United States. In any form, growth boundaries support "The key idea that imposing a defined boundary around a city beyond which development will be prohibited (at least up to some other jurisdiction) will simultaneously prevent sprawl outside the boundary and promote higher density inside it" [2].

From the second half of the twentieth century, urban growth management (UGM) instruments developed from 'simple' urban containment boundaries into comprehensive plans including a wider array of policy measures to restrain urban growth and promote selective development. Recently, smart growth policy packages have centered more on (dis)incentives than direct regulation. Thereby, the perception of urban growth has evolved from a problem to be contained, to an opportunity to fix past development errors and guide new developments to address current social issues [2-4]. As Calthorpe and Fulton state, 
"A multifaceted policy can reinforce a development tendency toward more compact communities, support efficient infrastructure investments, preserve open space, and encourage the revitalization of many declining areas [5]".

Despite the recognition that UGM instruments are multifaceted, Knaap and Nelson already noted three decades ago that, "Although UGBs are multi-objective instruments, most research on the effects of UGBs has focused on land values" [6]. This also holds true for the evaluative literature published in subsequent decades, which focuses primarily on analysing the effects of growth management strategies on land values and housing prices [7-11]. Additionally, there are many reviews of the effects of urban growth management on urban development patterns [12-16] and mobility [17,18].

We argue that a majority of these contributions evaluate growth management strategies by using quantitative indicators of surface areas, retail sales, land values, building lot sales transactions and traffic. Studies often identify growth management policies-without further elaboration-as independent variables tied to a particular geographical location, in order to evaluate their effects $[19,20]$. New contributions to the body of work generally suggest improvements in measurement methodology or add new case studies. These quantitative evaluations thus often implicitly assume that growth management policies are executed as they were intended, after which effects can be measured. This approach of evaluating UGM stresses the final stage of the policy cycle [21] and creates a blind spot regarding the events and decisions of earlier stages in which policy is conceived, formulated, and implemented. Furthermore, it is striking that there is hardly any work on the public support for growth boundaries.

Therefore, we argue that there is a need to look beyond the measurement of effects of urban growth management instruments and consider the institutional and discursive conditions in which they are formulated and implemented. This aim is supported by occasional contributions to the literature that do at least recognize the importance of cultural factors and institutional settings on the formulation and implementation processes of urban growth measures. After their statistical analyses of growth boundary effectiveness, Jun [12] and Gennaio, Hersperger and Bürgi [16] refer to the pertinence of political debates and circumstances on these policies, though they refrain from delving deeper into them. In other studies, the data on the broader context is there, but it is not given a prominent place in the analysis (e.g., Reference [7]). Moreover, Bengston et al., distil the key lesson that "implementation is critical" [22] because it determines effectiveness.

Other authors also point out the importance of institutional and discursive factors for the success of urban growth management. Margerum produces criteria for the evaluation of collaborative planning processes applied to the implementation of growth management strategies in South East Queensland, Australia [23] and Denver, Colorado [24]. The main conclusions of these studies are that growth management collaborations lead to an increased sensitivity to spatial problems on a regional scale, as well as to increased communication between governments. The studies also, however, find a weak political and community input into growth management projects, and stress the importance of these contributions. Knaap [25] points at the importance of citizens' perceived self-interest in growth management for its public support and Knaap and Nelson [6] also note the role of political tension in their evaluation of the Oregon land use program,

"The construction and implementation of UGBs in other urban areas is a protracted political process. Turf battles often arose between city and county governments and, in the larger metropolitan areas, between city governments [6]".

Finally, various authors call for more context-specific studies and nuanced analytic frameworks of the policy environments and governance structures in which UGM policies are situated $[2,3]$. In the words of James et al.,

"Efforts to manage urban growth tend to occur within the frameworks, conventions, and requirements of government structures-from the municipal to 
the national. However, this very much depends upon associated political and cultural systems [26]".

These contributions show that there is a broad awareness of the importance of the institutionalisation of growth management instruments for their success or failure. Yet, the analysis of the policy formulation and implementation phases is still rare in evaluations of growth management strategies. This paper aims to contribute to the body of work by focusing on the institutional and discursive context in which urban growth policies are formulated and implemented. To illustrate the importance of such a perspective, we analyse the growth management instrument of demarcating urban areas in the Belgian region of Flanders using the Policy Arrangement Approach (PAA). Section 2 outlines our research approach.

\section{Analysing the Institutional and Discursive Dimensions of UGM}

The PAA [27] describes the structure and institutionalisation of policy arrangements. These are defined as "the temporary stabilisation of the content and organisation of a particular policy domain at a certain policy level or over several policy levels" [28]. Through daily interactions between policy actors, patterns emerge that are more or less stable and that may include the "substantive delineation of the problem at stake and of possible solutions, but also the processes of give-and-take between the actors and the formal and informal rules according to which these processes take place" [29]. The Flemish spatial demarcation instrument analysed in this study is one such policy arrangement intended to restrain urban sprawl.

By distinguishing four dimensions of policy arrangements, the PAA analyses institutional patterns of change and stability:

1. The first dimension of actors and coalitions include governments, departments, private citizens, firms, and NGOs with a stake in the policy process.

2. The second dimension is rules of the game, defined as mutually agreed formal procedures and informal routines of interaction within institutions. These rules select the shape in which social interactions take place. For instance, procedures to involve citizens in the planning process lead to a certain kind of participation which may or may not have the intended effect and may or may not be satisfactory for those participating.

3. Thirdly, resources and power can mean material resources such as land and finances, but also knowledge and expertise. Funding agencies, incumbents of political office, and experts all possess particular resources in spatial planning which lead to the possession of various types of power and influence to affect the outcome of a policy process.

4. Fourth, policy arrangements are analysed in terms of discourses. This is a substantive dimension, as opposed to the former three, which are organisational dimensions of a policy arrangement. Discourses include the views and narratives of the actors involved in a policy process. Discourses contain and reflect norms and values, problem definitions, and preferred solutions to problems. The PAA draws a distinction between macro-level governance discourses and those at the level of the concrete policy issues at hand. These discourses may overlap or be at odds. For instance, in spatial planning, the strategic aims of a plan at the regional level plan can be opposed to the interpretations of citizens whose property is affected by it.

As Figure 1 shows, the four dimensions of policy arrangements are linked and their analysis only makes sense when all four are taken into account in their interconnectedness. Changes in one dimension are likely to cause changes in the others as well. For instance, the redefinition of a policy problem (discourses) may cause regulations to be altered (rules), different stakeholders to become involved (actors), and other knowledge and funding channels to become relevant (resources). This makes the PAA a starting point for an encompassing and dynamic analysis of policy processes. 


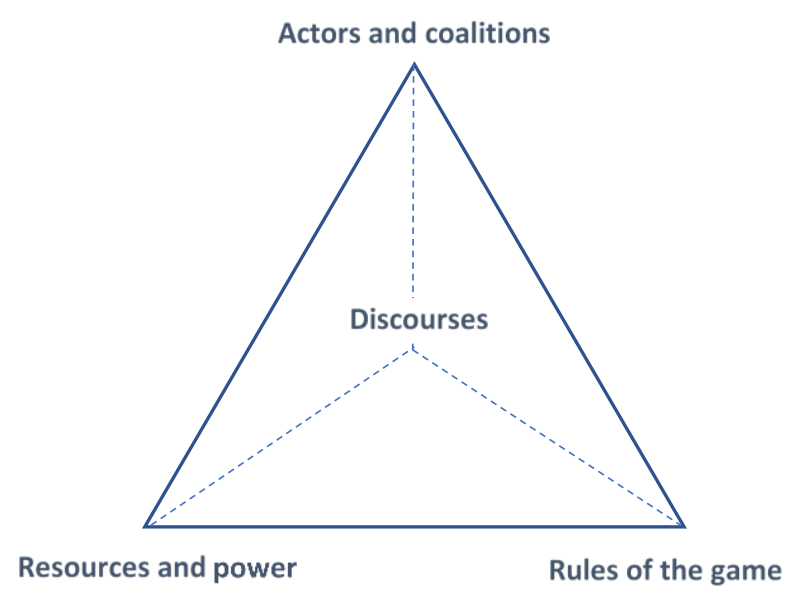

Figure 1. Schematic representation of a single policy arrangement. Adapted from Liefferink in Reference [29].

In this paper, the policy arrangement approach is used to highlight the institutional dimensions of urban growth management strategies. By taking this perspective, we can shed light on the conditions under which the Flemish instrument of demarcating urban areas was formulated and implemented in the Antwerp Metropolitan Area.

\section{Case Study: Demarcating Urban Areas in Flanders}

\subsection{The Belgian and Flemish Spatial Planning System}

Modern spatial planning in Belgium can be traced back to the Belgian law on town planning of 1962. This introduced a system of land use planning that led to the development of 48 national zoning plans covering the entire territory. Due to a liberal distribution of areas for housing and other functions in these plans, the landscape became increasingly fragmented. As a part of the federalisation of the Belgian state into semi-autonomous regions, authority over spatial planning in Flanders was devolved to the Flemish region in 1980. Under Flemish rule, further regulations stimulated fragmentation, but the land use planning system introduced in 1962 was kept intact [30].

Within the region, three levels of planning authority operate, each with their respective executive and administrative bodies. At the top, there is the regional level consisting of the Flemish government and the planning administration. The provincial deputation and planning office operate at the intermediate level. Locally, planning is handled by the municipal College of the Mayor and Aldermen and the municipal planning office. Between these levels, a relation of subsidiarity exists. The municipal level is concerned with local planning tasks, the provincial with matters that transcend municipal borders, and the regional with issues that concern the region as a whole. Appeals against decisions are possible from the local to the provincial, and ultimately, the Flemish level [31].

In part due to the adverse effects of the land use planning system on the region's spatial pattern, a new planning system was introduced in the Flemish region in the second half of the 1990s. Now, competent authorities on all three levels were tasked with developing a structure plan containing an overarching strategic planning vision, and spatial plans ${ }^{1}$ with decisions to implement this vision.

In the terminology of the most recent comparative study of European spatial planning systems - the ESPON COMPASS project-the Belgian ${ }^{2}$ spatial governance and planning system (SGPS) is categorised as one in which market-led development is prevalent. This means that market actors regularly and informally influence spatial policy decision making to pursue their private goals. Additionally, building permits are oriented towards protecting private property, which makes the implementation of comprehensive spatial policy

In Dutch: ruimtelijke uitvoeringsplanning or RUPs.

The COMPASS typology merges insights about the three independent planning systems in Belgium into one national type. 
more difficult. Along with the SGPS of 12 Mediterranean and Eastern-European countries, and more so than most other Northern and Western European countries, Belgium leans towards a conformative planning model, where binding general plans determine land use and development rights to a large degree [32]. The legacy of the national zoning plans can clearly be seen here. However, gradual modifications are possible, which is illustrated by interventions made to the zoning plans by the Flemish RUPs at all three levels.

\subsection{Restraining Sprawl in Flanders}

As a result of its spatial planning history, Flanders is one of the most densely urbanized regions in Europe with a built-up area of 33\% [33]. The region is characterized by many of the problems accompanied by such a condition: the fragmentation of nature posing a threat to biodiversity, heavy congestion, a high traffic mortality rate, noise and air pollution, high public expenditures for building and maintaining extensive road and utility networks, insufficient water infiltration leading to flood risk, and finally, the unfavourable aesthetics of a fragmented landscape [34-36].

Because the growth of spatial fragmentation and its problems have long been recognised as an undesirable trend in Belgium [37,38], in 1997, the Spatial Structure plan for Flanders (Dutch: Ruimtelijk Structuurplan Vlaanderen, henceforth: RSV ${ }^{3}$ ) was developed, accompanied by new planning legislation. ${ }^{4}$ The RSV contains an explicit growth management strategy for Flanders 5 . Starting from a vision represented in the metaphor "Flanders Open and Urban", the RSV "(...) strives for a selective concentration of the growth of living, working and of the other social functions in the cities and the nuclei of the countryside" [40]. Therefore, $60 \%$ of new housing in Flanders is projected to be realised in demarcated "urban areas" and a maximum of $40 \%$ outside them, thereby freezing the areal distribution of urbanization as it was in 1991 and halting the proliferation of urban sprawl. In order to achieve these goals, the RSV distributes quotas of land to be zoned for housing and other functions (industry, services, agriculture, nature) among the Flemish provinces and urban areas, which are to be realized by 2007.

As a part of this strategy, 13 larger and 44 smaller cities designated in the plan are subject to a spatial demarcation instrument that includes a statutory line drawn at plot level around them and parts of their fringe municipalities. Within these urban areas, a concentration and densification of residential and economic functions is envisioned. As a comprehensive growth management strategy, the demarcation process also aimed to promote cooperation between the political, administrative, and societal actors of the urban and suburban (fringe) municipalities to develop a shared vision of the development of the urban region. Within the demarcated area, a number of planning regulations are in effect, the most important being a minimum housing density of 25 units per hectare ${ }^{6}$. The line itself does not change any existing zoning or administrative borders as the new planning regulations only apply to new building permits ${ }^{7}$.

Though there are some positive examples, the demarcation of the urban areas is generally regarded very critically in Flanders [41,42]. The structure planning framework in Flanders did not manage to reduce the large amount of residentially zoned areas in Flanders that has existed since the 1970s $[38,43]$. By not meeting attempts at spatial concentration

3 This text adheres to the original Dutch acronyms of the planning documents to cater to those familiar with planning in Flanders.

4 For more information on the RSV's design and implementation, see [30,39].

5 In addition, there was a set of policy measures aimed at urban revitalization and making cities more attractive places to live; however, as this falls under the policy domain of Domestic Affairs rather than spatial planning, these are left outside the purview of this analysis.

6 The prescribed minimum density in the rural areas outside the urban growth boundary was 15 units per hectare.

7 While the demarcations of urban areas in Flanders have some characteristics of smart-growth strategies, they completely lack the involvement of market actors as well as redistribution of development opportunities via transferable development rights (TDR). Furthermore, despite initial intentions, municipalities and provinces were not treated as equal partners in the process. The demarcations are, therefore, discussed here as a classic growth management strategy that in Bae's [2] typology can be characterised as an example of an urban growth boundary with accompanying minimum density zoning, infill and residential unit ordinances and a limitation on new residential development outside the growth boundary. 
with a reduction of supply in the suburban and rural parts of the region, the demarcations proved largely inconsequential for the region's spatial pattern.

The intended city-regional cooperation was only achieved in the smaller and "less complex" urban regions and land use logic has emerged as dominant over a more openended structure planning approach $[44,45]$. Reflecting a decade after the approval of the RSV, one of its main authors concludes that demarcation plans have become nothing more than "an inter-municipal local land use plan" which is "an improper use, more strongly, a misuse of the [demarcation] concept that leads to the undesired further juridification of spatial planning" [46]. This raises the question about the conditions of the demarcation instrument's formulation and implementation.

\subsection{Demarcating the Antwerp Metropolitan Area}

Our analysis focuses on the spatial demarcation process of Antwerp. Because it is the largest demarcation process in the Flemish region, it provides the richest selection of findings to analyse the implementation of the growth management policy ${ }^{8}$. The Antwerp urban growth boundary covers parts of 19 different municipalities, two of which lie outside the province of Antwerp in the neighbouring province of East-Flanders. The map in Figure 2 shows land coverage in the greater Antwerp area in 2015. Superimposed on the map is the demarcation line of the Antwerp Metropolitan Area. The map illustrates that Antwerp is a concentrated urban core with a fringe characterised by urban sprawl and ribbon development, both inside and outside the demarcated urban area. Next to the demarcation line, the plan includes 24 areas to be rezoned in order to achieve the quota set for the various spatial functions outlined in the RSV.

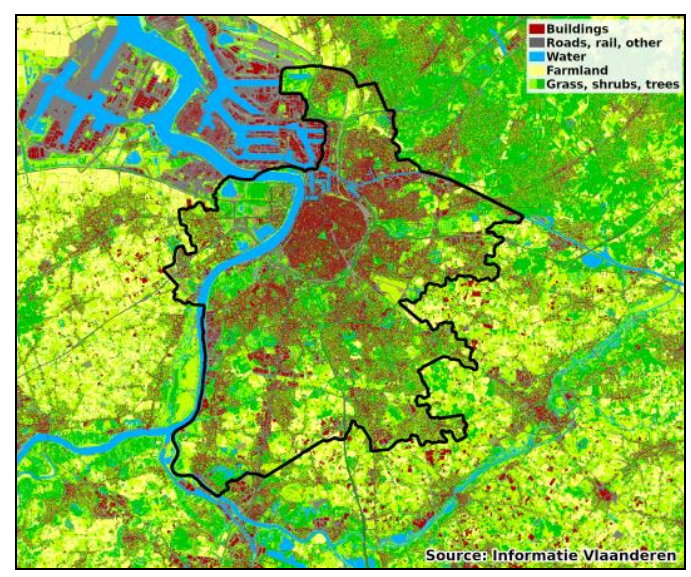

Figure 2. Land coverage in the greater Antwerp area 2015 including the Metropolitan Area demarcation $[48,49]$.

Planning regulations for the urban area are recorded in a regional spatial plan (Gewestelijk Ruimtelijk Uitvoeringsplan or GRUP) for the Antwerp Metropolitan Area [50]. It was designed by a private spatial planning firm, finalized by the regional planning administration and approved by the Flemish government. The timeline in Table 1 shows that this process spanned a period of six years (2003-2009), excluding the legal procedures that followed.

8 The demarcation process of the Flemish urban area surrounding Brussels is arguably even more complex and hence rich in empirical terms. However, as Brussels is a separate region within Belgium, its demarcation is strongly characterised by communitarian politics [47] and is, therefore, not typical of the demarcation processes in Flanders in general. 
Table 1. Demarcation of the Antwerp Metropolitan Area: Timeline.

\begin{tabular}{|c|c|}
\hline Period & Event \\
\hline April 2003 & $\begin{array}{l}\text { Start of demarcation process, round of exploratory talks with municipalities conducted by planning } \\
\text { firm led by a former provincial official. }\end{array}$ \\
\hline June 2004-April 2005 & $\begin{array}{l}\text { Three "steering group" meetings of Flemish officials, provinces and municipalities, leading to } \\
\text { various iterations of a metropolitan vision. }\end{array}$ \\
\hline 15 April 2005 & $\begin{array}{l}\text { Final report concluding the vision process. Contains proposal of demarcation and areas to be } \\
\text { rezoned. End of assignment for planning firm. }\end{array}$ \\
\hline $2007^{9}$ & $\begin{array}{l}\text { Process restarted by administration. August 23rd plenary meeting on the design of the regional } \\
\text { spatial plan (GRUP). }\end{array}$ \\
\hline April-June 2008 & Environmental and safety assessments completed. \\
\hline 1 July 2008 & $\begin{array}{l}\text { Minister of Spatial Planning presents the spatial demarcation to mayors of municipalities involved in } \\
\text { plenary meeting. }\end{array}$ \\
\hline 5 September 2008 & $\begin{array}{l}\text { Preliminary approval of the Flemish Government of the demarcation Antwerp Metropolitan Area, } \\
\text { press release. }\end{array}$ \\
\hline $\begin{array}{l}\text { October-December } 2008 \\
8 \text { April } 2009\end{array}$ & $\begin{array}{l}\text { Public inquiry. Objections considered by the Flemish Committee of Spatial Planning (Vlacoro). } \\
\text { Report of the Flemish Committee of Spatial Planning. }\end{array}$ \\
\hline 19 Jun 2009 & $\begin{array}{l}\text { Definitive approval of regional spatial development plan of the demarcation Antwerp } \\
\text { metropolitan area. }\end{array}$ \\
\hline 2009-2012 & Council of State hears several procedures against the demarcation GRUP. \\
\hline
\end{tabular}

\subsection{Data}

The following empirical analysis is based on a study of the officially published plans and policy documents. From 2015 to 2018, in-depth interviews were conducted with 17 planning experts and officials at the regional level (designated E\#), 3 local planners (A-S\#), 5 politicians (A-P\#), and 4 citizen-activists (A-A\#). ${ }^{10}$ These interviews were all transcribed and coded. The private planning firm granted access to its archives, while several key respondents provided documents from their personal archives. An analysis of 84 articles in the local newspaper mentioning the demarcation between 1997 and 2017 provided additional context. In the public inquiry on the Antwerp demarcation, the Flemish Committee of Spatial Planning (Vlacoro)-consisting of planning experts, government representatives, and civil society actors-summarized and advised on more than 6000 objections to the preliminary GRUP bundled in petitions, 2100 individual objections, and 12 recommendations by local and provincial governments. The responses in the resulting report [51] were coded by the researchers to show the argumentations for accepting or rejecting the objections. Finally, policy evaluations of various other demarcation and city-regional cooperation processes were drawn upon $[42,44,45,47,52,53]$.

\section{Analysis: Safeguarding the Future}

Table 2 provides a schematic summary of the analysis of four phases of policy formulation and implementation in the demarcation process. By distinguishing the four dimensions of the PAA in each phase, we show how the land use logic gradually overtook the vision of combating urban sprawl. Each phase is explained in the subsections below.

9 Politicians in Flanders are allowed to have concurrent seats in both local and regional bodies, creating close ties between local and regional politics. Therefore, the process was halted between 2005 and 2007 pending the outcome of local elections taking place 8 October 2006.

10 There were more interviews conducted with local planners, politicians and citizens since the demarcation of the urban area surrounding the city of Mechelen was also researched. As this paper only reports on the Antwerp case, these are not included here. 
Table 2. Policy arrangement analysis of the demarcation of the Antwerp Metropolitan Area.

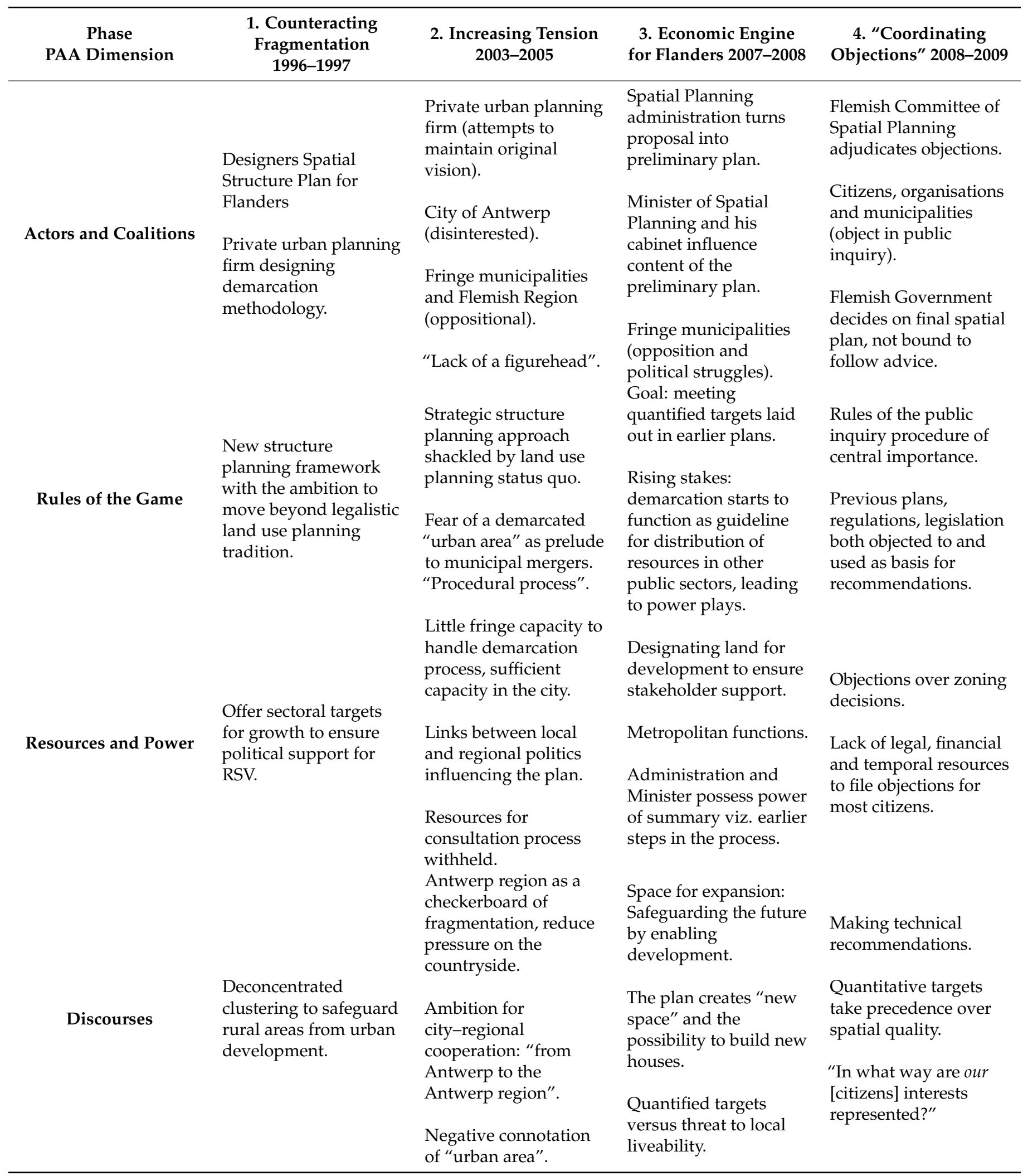

Between the original vision of the demarcation instrument and the way it is presented in the preliminary version of the spatial plan for the Antwerp Metropolitan Area, a major discursive shift occurred. On 5 September 2008, a press release titled “Antwerp's future safeguarded by the demarcation process of the metropolitan area" marked the Flemish 
Government's preliminary approval of the demarcation plan. The plan is promoted as creating new development opportunities, states that it "provides new space" and includes a list of amounts of land area (re)zoned for housing, nature and industry, which is translated in Antwerp's local newspaper as: "the GRUP enables the construction of 8249 houses" [54]. Additionally, the press release mentions decisions on a number of "metropolitan functions" such as regularising a golf course, finding a location for a soccer stadium and the expansion of the local airport. The minister of spatial planning is quoted,

"Today we have arrived at a balanced proposal in which we safeguard the future of the Antwerp region and make the Antwerp metropolitan area even more attractive for working, residing and living ${ }^{11 "}$.

The discourse of a press release may be expected to present the ultimate legitimation for a spatial plan to the broader public. Here, it shows a dominant logic of land use planning with land and building opportunities represented as resources made available through zoning. This discourse is almost the opposite of the vision of the Spatial Structure Plan for Flanders under which the demarcation instrument was introduced. Its focus has changed from safeguarding rural areas from development, to safeguarding the future by making development possible. Why did the authors of the press release and their political superiors opt to present the plan in terms of the land use logic dominant in Flanders throughout the second half of the twentieth century, instead of in the terms introduced in the Spatial Structure Plan for Flanders ten years earlier?

\subsection{Phase 1: Counteracting Fragmentation (1996-1997)}

Despite a discourse that underlines the necessity to counteract urban sprawl, the tension between land use logic and strategic planning is already present in the two documents that lie at the root of the demarcation processes. These are a preparatory study to determine a methodology for demarcating urban areas, commissioned with a private urban planning firm [55] ${ }^{12}$, and the Spatial Structure Plan for Flanders itself.

The preparatory study mentions the spatial fragmentation of the Flemish settlement structure explicitly as the main reason for developing an urban growth management instrument. It states that, in Flanders, there is currently no clear separation between "urban" and "open space" and it introduces the ambition to break with the trend of a primarily land use-oriented spatial policy. The study presents this intent as the:

“ (... ) directed interweaving and bundling of functions and facilities, among which the economic functions, within the urban areas, above all absolute priority is to use and manage the existing urban structure as well as possible $(\ldots$ ) the preservation and where possible strengthening and expansion of open space. (...) This breaking of the trend aims for the protection of open space, counteracting the fragmentation, and the separation of open space and urban areas [55]".

In the RSV itself, this is translated into the central strategic spatial policy concept of deconcentrated clustering: striving for a greater bundling of activities within Flanders' decentralized urban structure. The principle is positioned explicitly as a means of combatting urban sprawl:

“Deconcentrated clustering goes against unbridled suburbanisation and fragmentation and thus reduces the pressure on the countryside [39]".

Combatting sprawl in order to reduce-or at least restrain - the growing negative effects on mobility, environment and cost of public services was, hence, originally one of

11 All quotes from interviewees, press and policy documents are translated from Dutch by the authors.

12 In Flanders, these firms perform a mix of architectural, urban planning and research work with some of their staff moving freely in both academic and practitioners' circles. In fact, one of the firm's directors played an important role in developing the RSV itself. Furthermore, building private sector capacity through developing expertise regarding the new structure planning framework was a deliberate strategy of those designing the RSV to improve the quality of its implementation [1]. 
the main goals of this first overarching spatial plan for the Flemish region. The demarcation of urban areas was to be the prime instrument to realise this:

"The demarcation of the urban areas is considered an essential policy measure in order to stop the urban flight and ribbon development, to be able to realise a "supply policy" regarding additional housing and space for economic activities and safeguard the rural areas from urban development ([39], p. 212)".

This discourse is found in the vision section of both documents and, as such, outlines a number of "grand goals" for the future without going too deeply into particulars. The documents also show that the original methodology to arrive at a demarcation proposal (delineating an urban area and identifying certain areas for rezoning to create a supply of well-situated development areas) was a rich one that considers many socio-spatial indicators before proposing a desired spatial structure.

In terms of actors, the process was supervised by the Flemish regional authorities, though shaping a vision for the urban area itself was considered a task for the municipalities. Therefore, the intent was to give provinces and municipalities the opportunity to provide their input at various moments in the process.

However, this method stood in a tense relationship with the customary practice of land use planning. The newly introduced planning system had to operate against the background of the preceding generation of zoning plans that fix the permitted use of every plot of land in the Flemish region and that continue to shape the spatial-political reality up to this day. While the new planning system preferred a more open strategic "structure planning" process over the existing "passive" national zoning plans, many actors were used to a rule-based practice oriented to the legal certainty of zoning. One of the designers of the RSV mentions the tension between these two paradigms:

"We were not always very happy with that. Because what we wanted to do was partly at odds with the traditional zoning plans. Those are aimed primarily at legal certainty ( . . . ) while we would have preferred to depart from a vision and then see which technical, juridical conditions were necessary to transform those interventions in reality (E2)".

There was a keen awareness among the promotors of the RSV (actors) that the success of its strategic spatial planning vision depended on discursive and institutional support of other public and private actors. As part of that strategy, zoning logic did serve a purpose as a resource to ensure their cooperation when implementing the RSV's policy goals by promising them possibilities of future spatial expansion. Thus, the preparatory study already recognizes the importance of sectoral targets for housing, industry, et cetera, when it states that "the translation of these [targets] to an urban area is precondition to establish a demarcation." While concluding that vision is important to achieve the desired spatial structure, the study emphasizes that:

"The spatial concepts for an urban area have to be aimed at possibilities for expansion. Especially the targets regarding housing and commercial areas have to be translated to the terrain [55]".

Despite the presence of this tension, the vision of counteracting spatial fragmentation was carried forward into the Antwerp demarcation process by a key actor: the same urban planning firm that had produced the preparatory study was commissioned to produce the demarcation proposal for the Antwerp Metropolitan Area.

\subsection{Phase 2: Increasing Tension (2003-2005)}

While the private planning firm could be considered a champion for the new structure planning approach, when the time came to demarcate the Antwerp Metropolitan Area, it quickly ran into other actors: a disinterested City of Antwerp and opposition from both its fringe municipalities and the Flemish Region. This would lead to a loss of resources for broad consultation and the development of city-regional coordination. Lack of for- 
mal political support seriously weakened the vision of safeguarding the future through combating urban sprawl and provided room for the land use paradigm to come to the fore.

As a first step towards a demarcation plan for the Antwerp Metropolitan Area, the private planning firm drew up a proposal in a consortium formed with subcontractors responsible for communication and citizen participation. Subsequently, an extensive formal consultation programme was planned. The proposal's discourse reflects the RSV's evaluation of space in Flanders, characterising the Antwerp Area as a "checkerboard of fragmentation", a network city, or a "polycentric whole of fragments, of poles, of dense and less dense places" [56]. To guide development, the proposal aims to realise a supply of development areas within the metropolitan area of Antwerp; it reads:

"The pressure on the countryside can only be controlled by catering to the spatial needs for housing and commercial activities in the urban area ([56], p. 13)".

In order to realise these aims, a demarcation line is drawn and proposals are made to activate some (residential, industrial and commercial) reserve areas, while eliminating others. The document also includes proposals for infrastructure renewal, investments in housing and culture, regional, transnational and global networking, and the creation of a metropolitan green structure as goals accompanying the demarcation exercise. Finally, by explicitly extending mentions of "Antwerp" to "the Antwerp region"13, the demarcation proposal repeatedly underlines that this is an effort to be made not just by the city of Antwerp, but by all of the municipalities involved (discourse). It states that cooperation can be realised in a "strong and coherent metropolitan framework" which could be pursued by a potent planning administration on metropolitan level or "a platform that supports the metropolitan policy" ([56], pp. 35, 51, 149).

However, the ambitious vision of counteracting sprawl through the development of a spatially concentrated city-region laid out in the demarcation proposal was impeded by other actors: the Antwerp fringe municipalities and the Flemish Region itself. First, the complex and time-consuming policy context in the Antwerp region restrained working towards city-regional cooperation. The relationship between the city and the fringe municipalities is historically fraught with tensions as far as spatial planning is concerned (see Chapter 2 in Reference [57]). As a part of these tensions, fringe municipalities often self-identify as rural, to stress their independent character as opposed to the (urbanised) City of Antwerp [58]. Therefore, the discursive concept of "urban area" quickly acquired a negative connotation, which, in turn, resulted in political and public resistance to the planning process. There was also fear in some fringe municipalities that the demarcation would be a prelude to future mergers, causing local politicians to start attending meetings originally intended for Flemish and local planning officials. The planning firm reported, nonetheless, that support for the metropolitan area was growing steadily at this time. Various respondents still recall a two-day workshop with stakeholders held in an abbey in one of the fringe municipalities, which acted as "neutral ground" outside Antwerp city limits according to one respondent (A-P5).

The early involvement of local politics was initially welcomed by the Flemish administration as an opportunity to generate support for the project. At the same time, though, the regional level had a low estimation of municipal expertise-also found in other demarcation processes [45]. Building up municipal planning capacity as a resource was another aim of the RSV, but it had not advanced very far at the time of the Antwerp demarcation. When asked about the time available to occupy oneself with the demarcation process, one fringe municipality planner responds:

"Yes, very limited you know? The main task is handling permits, planning is a task at the side. So, I didn't really treat it very substantially (A-S2)".

13 This sounds more subtle in Dutch: een verruiming van "Antwerpen" naar "het Antwerpse" (p. 37). A formulation with sufficient vagueness not to be politically threatening. 
At the Flemish level, in 1999, a Liberal Party Minister had taken the place of ChristianDemocrat and Socialist predecessors who had initiated the RSV and the new planning framework. From this moment, measures aimed at restraining growth outside the urban areas were weakened. In terms of rules, this resulted in a failure to meet the envisioned supply policy in the urban areas with a restrictive land development policy beyond them $[30,59]$. The planning firm was also not granted permission by the Flemish administration to execute the public consultation part of the assignment and was not paid for work already performed. Consequentially, little resources were spent on promoting an agenda of city-regional cooperation. The private planning firm also noted the lack of a key public figure (actor) to support the strategic spatial planning vision behind the demarcation process. The then mayor of the city of Antwerp was approached to fulfil this pioneering role, but declined because he felt that involvement of his office would fuel distrust in the fringe municipalities.

In fact, the City itself took a back bench in the demarcation process. As one city planning official summarized the attitude: "We'll do it because Flanders is doing it. But we'll decide for ourselves what exactly we'll have to do" (A-S1). For any rezoning it wanted to initiate, it had ample planning resources to organise itself and it was, therefore, not interested in the Flemish rezoning exercise. Interviewees also report a direct link between city politicians and ministers of their party in the Flemish Government. This "vertical connection" functioned as a resource to influence important decisions and resulted in the private planning firm and regional planning officials being taken out of the loop for all the important dossiers regarding the city.

Though discursively still representing the vision of the RSV, the tension between this vision and the land use logic is already visible in the 2005 final demarcation proposal. The erosion of the RSV's vision can be seen where the text explicitly states that it does not want to interfere with the borders, plans and powers of the individual municipalities and does not aim to create new administrative authorities. Despite repeatedly stressing the need for city-regional cooperation, the text mentions the low levels of support and enthusiasm for the demarcation process. The approach, lacking resources for the consultation programme, is recontextualised as an approach through "predominantly informal contacts". The goal of working towards city-regional cooperation was henceforth abandoned in favour of what one interviewee calls a much more "procedural process" (A-S1). Another city official recalls:

"Although the planning firm started from the ambition of the RSV, from a demarcation line to a programme for the Antwerp region, they were not allowed to work like that, they had to return to the old way of rezoning and -colouring. In effect this is almost a zoning plan (A-P5)".

\subsection{Phase 3: Economic Engine for Flanders (2007-2009)}

When the preliminary demarcation plan was published in 2008, its discourse had transformed into one of "creating space" for expansion, omitting completely the RSV's aim of counteracting unbridled suburbanisation and fragmentation and reducing pressure on the countryside. The prime discursive legitimation presented in the preliminary plan is the continued development of the Antwerp area's position as metropolis and economical engine for Flanders. This, was argued, requires improvement of the quality of the locations for employment, housing, metropolitan services, natural and landscape structures, roads and public transport [50]. The preliminary plan only contains two cursory mentions of the spatial fragmentation of the Antwerp area before moving on to discuss quantified targets for housing and industrial development. The land use logic that already played a role in the earlier phases of policy formulation-both as the legal inheritance of the previous planning system and as resource to ensure stakeholder support-takes centre stage in this phase. Thus, the process reflects the exact political-institutional dynamics of land development leading to the spatial fragmentation that the initiators of the RSV sought to transform and contain. Reflecting critically on the process, one city official concludes that the demarcation 
was reduced to "a number of banal zoning changes" but not to a serious action plan, that, for instance, also included a mobility policy (A-S1).

The Flemish spatial planning administration processed the demarcation proposal into a regional spatial plan. This means that administration and the cabinet of the Minister were the actors that possessed the power to represent and foreground certain voices and arguments from the previous stage and filter out others. Possessing this "power of summary" [60] without the obligation to offer legitimation, the regional administration could also make a different selection of areas for rezoning. Indeed, at this stage, several areas proposed for rezoning and development in the previous phase were left out. Others were added that were not included in the earlier demarcation proposal, either because they were deemed unfit for development by the private planning firm or because they were advised negatively by the City. Eliminating the already existing zoning of a number of areas is no longer mentioned. Finally, some areas for "metropolitan functions" are inserted into the plan. These provide zoning for a water purification installation, a soccer stadium, regularization of a golf course and a commercial area attached to the local airport. Zoning interventions like these were not conceived as part of the demarcation instrument though it could be argued that finding locations for these kinds of supra-local functions is not contrary to the vision of developing a coherent metropolitan area. Yet various interviewees felt these metropolitan functions to be the result of political deals between the City and the Flemish Government and the lobbying of private market parties. In particular, the minister who was elected in the Antwerp constituency and hence had a local political stake in the demarcation process (E3, A-S1, A-P5). Overall, we can thus conclude that, in this phase, the growth management logic of drawing development to some zones in order to prevent it in others was dropped. Despite their caution, the municipalities had been fairly constructive partners during the production of the private planning firm's demarcation proposal. This changed when the classification of urban areas was adopted by other policy sectors as a criterion (rule) for the allocation of public resources such as healthcare facilities and cultural centres ${ }^{14}$. This raised the stakes of (not) falling within an urban area and led to "power plays" between the stakeholders involved reminiscent of the turf battles described by Knaap and Nelson [6]. Similar to the strategy of the city, politicians from fringe municipalities attempted to safeguard their municipality's interests at the Flemish level by exerting influence through "vertical" party lines as well. Furthermore, the animosity between city and fringe came to a head. One interviewee in the Flemish Administration describes the process as:

"How can I as a city gain power over the adjacent municipalities, and how can I as fringe municipality keep the power of the city out? That's what it came down to. And absolutely nothing more, no cooperation (E1)".

In some municipalities the demarcation became the subject of local political struggles. Opposition parties politicized the demarcation dossier and attempted to co-opt citizens' protests (see also Coppens, Van Den Broeck and Van Wymeersch [53]). One mayor viewed the opposition's stirring up of fears of being absorbed by the city as a strategy of keeping the majority on its toes (A-P3). However, majority politicians resisted the demarcation as well, in sometimes fateful discourse. A local alderwoman is quoted in the press:

"Because of the plans, some farms will be doomed to disappear since the area will have become unliveable (Gazet van Antwerpen, 21 November 2008)".

\subsection{Phase 4: "Coordinating Objections" (2008-2009)}

Spatial plans in Flanders, like that of the demarcation, are subject to a public inquiry prior to approval by the government. In this last phase of the policy implementation

14 A point interesting in its own right. The adoption of planning categorizations by other policy sectors could be regarded as a desirable intent of a strategic spatial planning instrument. In the Flemish case, however, this led to struggle and dissatisfaction which expressed itself in a lack of cooperation at the local level that then extended to the Flemish regional level. 
process, it becomes clear that the ambition to realise the demarcation in line with the original strategic spatial planning vision has completely withered away and has been replaced by a predominant focus on distribution of resources and rules of the game. In this step in the process, the public inquiry instrument acts as a "regulative device" [60] that takes up some voices and neutralises others. It marks a genre-shift in the planning process from formulating (beneficial) spatial policy to responding to objections. The responses formulated by the Flemish Committee of Spatial Planning to the objections made in the public inquiry were analysed by the researchers. Figure 3 shows the types of the 1375 arguments used ${ }^{15}$.

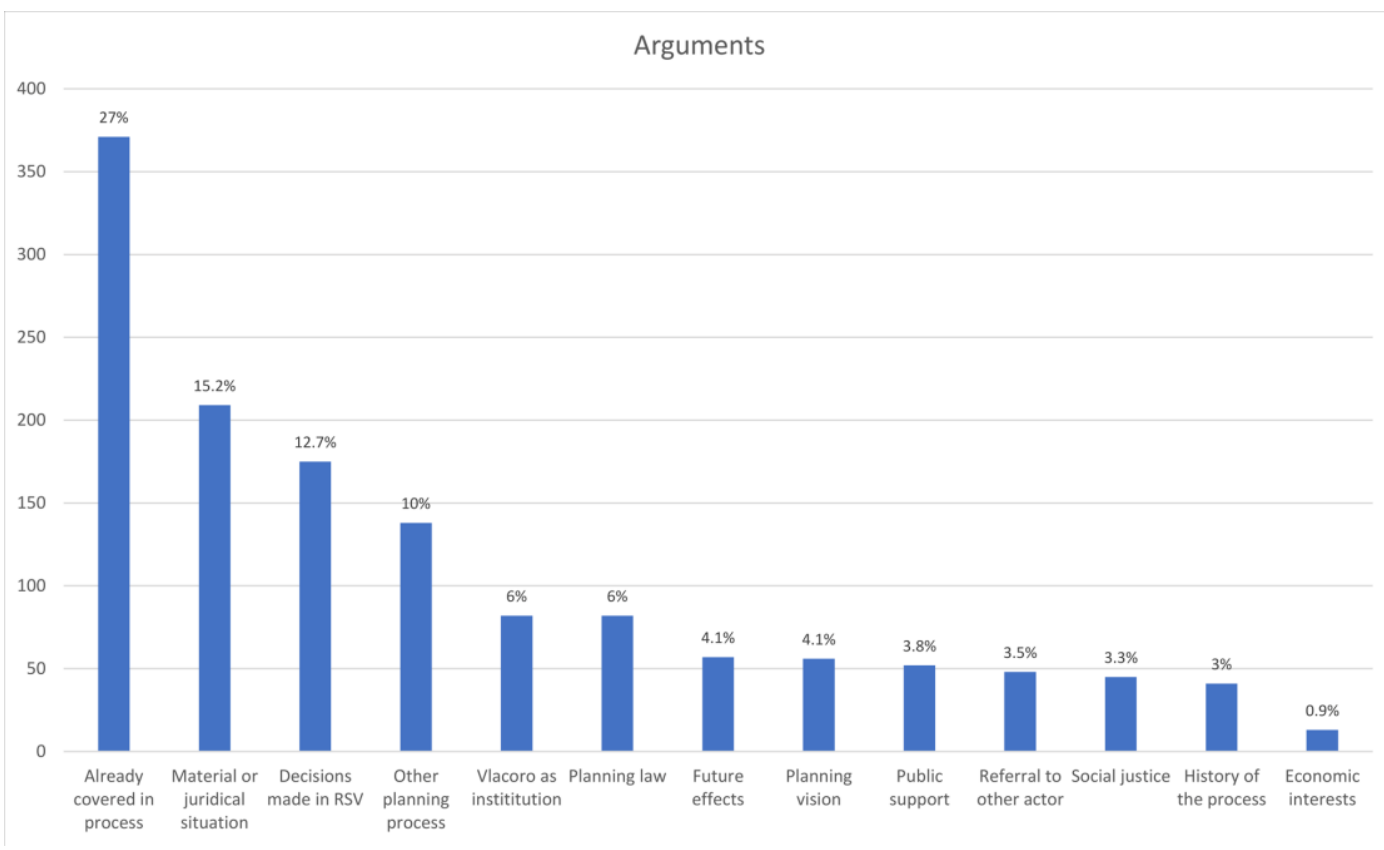

Figure 3. Arguments used in the responses to objections (including internal references).

Overall, the original strategic spatial vision of restraining sprawl in Flanders played no significant role in the objections to the plan. With only $4.1 \%$ of responses referring in one way or another to the spatial vision, it was not a major argument in the responses of the committee either (Figure 3). Nor did the chairman of the Committee consider adjudicating objections on the basis of the original planning vision its task. They rather took a rule-based view where the Committee is mostly focused on "coordinating technical objections" so the plan could ultimately be approved:

"The objections had to be coordinated and then we expect from Vlacoro a technical recommendation. ( ... ) Yes, it was a technical committee. So, in principle you have to depart from the RSV that was approved by parliament. Vlacoro did not judge that. It's more about: How shall we propose to solve these technical objections? (E4-1)".

The public inquiry rather triggered responses of citizens and other parties who felt their (landed) interests to be threatened by the urban policy within the demarcation line. This can be seen in the numerous objections that focus on land use type as a resource (re)distributed by the plan:

"The regulations for the natural area are unclear, can I build a stable for animals, does the area need to be fenced in, can the terrains be grazed, ... ([51], p. 14)".

15 These numbers include "internal references": responses to objections that refer to previous responses in the report. 
"The 33 ha of the industrial zone is too little considering the high target number. One wonders whether the site doesn't have the potential to incorporate more ([51], p. 33)".

"Why is the Fort of Kruibeke included in the demarcation and not that of Zwijndrecht? The fort of Kruibeke also needs to be excluded from the demarcation ([51], p. 33)".

There are also many procedural challenges to previous plans, regulations, urban planning legislation, and the authority of the Flemish Government to make zoning decisions usually made by municipalities. Most of these, however, have a clear aim of stopping or promoting zoning decisions. The resource-oriented focus of the way urban growth management was implemented through this regional spatial plan was also noted by the committee in its general remarks:

"The plan is strongly based on the obligation to realize the quantitative targets, which means that there is sometimes less attention left for the spatial quality of some proposed urban developments ([51], p. 102)".

Although the public inquiry instrument is designed to allow the voice of citizens and interest groups to be heard, it functions as a regulative device where the "right kind" of discursively and institutionally framed objections (predominantly of a rule-oriented legal nature) are more likely to succeed. In fact, most objections are rejected, or-another example of the power of summary mentioned in Section 4.3-recontextualised and referred to the committee's general remarks (Figure 4). One citizen-activist who led a local group that opposed the inclusion of his neighbourhood in the demarcation summarizes the difficulty of mobilizing the resources and knowledge to phrase objections:

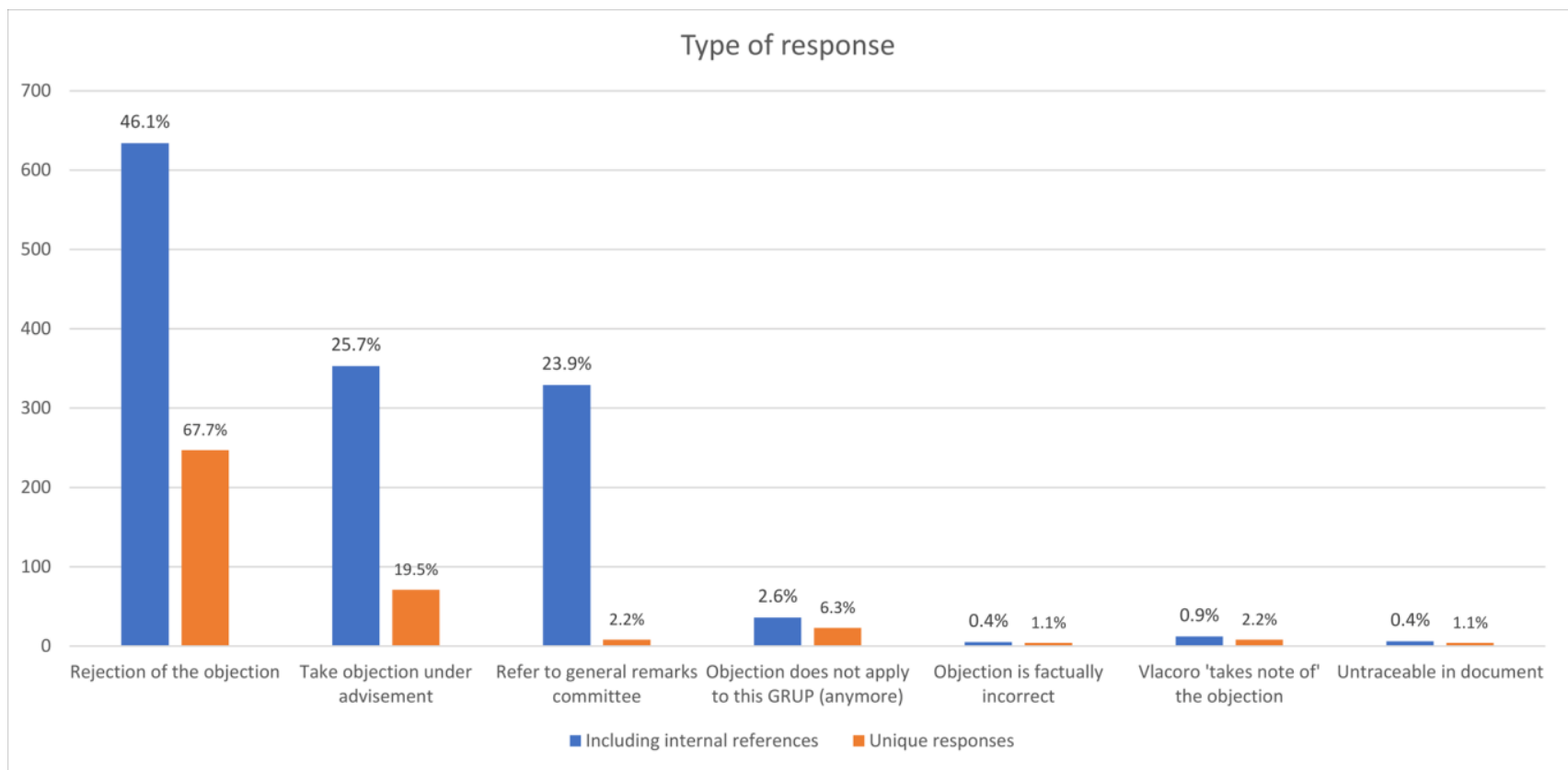

Figure 4. Responses considered in the public inquiry.

There is no capacity. It's almost impossible as a citizen nowadays to object properly against a complex plan. And then you have to know the procedures too. Planning law is tremendously complex. You can't know that as a citizen, you have to hire a very expensive specialised lawyer. There is no money for that. Who is going to gather that? Who will pay for that? And you have to do all of that within a month. That's practically impossible! (A-A1). 
Ultimately, the public inquiry led to the elimination of three of the twenty-seven areas to be rezoned. A fourth area was retracted by the Flemish Government a year after the approval of the final demarcation plan in 2009. Four lawsuits were filed with the Council of State, but these only aimed to annul parts of the metropolitan area developments due to local concerns and did not pertain to a larger strategic spatial planning vision. As mentioned by the respondents, filing lawsuits requires resources that only specific actors are able to mobilize: time, knowledge and skills to construct a well-documented dossier and the financial means to hire specialized legal counsel. This left most citizen-activists disillusioned with the process and the value of filing objections:

And apart from the number of objections you filed, or the number of signatures you collected, that is of no import. The law is the only thing of import. [Politicians say] we belong in the urban area so we can't say no [to development]. -Yes, but what about our arguments? In what way do you represent our interest? The interest of the common citizen, of the current residents? And there is absolutely no answer to that (A-A2).

Thus, the public inquiry instrument could not ensure the implementation of the original policy vision of restraining sprawl, but served instead as a regulative device to address public participation in a way that maintained the tried and true practice of zoning logic with its emphasis on rules and resources. The result is captured by one rather disillusioned planning official:

And what it became in the end is at its Belgian, right? Something very administrative, something legal-technical, zoning, securing, putting it into concrete. Was that the intent? I don't think so, but oh well. That's the only thing people know in Flanders right: securing, juridical (knocks on table). Which rights do I have, up to which plot? And that entire structure planning philosophy is translated in demarcations at the plot level, property titles yet again. What is allowed, what isn't? That uncertainty of "in time, what could this become??" A Fleming doesn't want that (laughs) (E3).

\section{Conclusions}

Despite a broad recognition in the literature that "implementation is critical" [22], contemporary evaluations of growth management strategies still mostly take the shape of quantified measurements of effects such as land values and housing prices, where it is often implicitly assumed that policy was implemented as it was intended. In this paper, we argue that understanding the formulation and implementation phases of these spatial policy instruments is of key importance to gain insight into the conditions of success and failure of growth management strategies.

This argument is illustrated by the analysis of the formulation and implementation of an urban growth management strategy in Flanders, Belgium. Using the Policy Arrangement Approach, it was shown how the institutional dimensions of actors, rules, resources and discourses in the demarcation of the Antwerp Metropolitan Area interrelate to produce an outcome almost diametrically opposed to the original planning vision of reducing urban sprawl. This vision collapsed during implementation where the new structure planning framework was mostly recontextualized in terms of its still active land use predecessor. The orientation towards the protection of private property characteristic of the Belgian spatial governance and planning system, as noted in the ESPON COMPASS classification, can be seen here. This is illustrated by the discursive presentation of land as a resource for new developments and a concomitant focus on the legal aspects of land use planning. In the Antwerp Metropolitan Area, the intent to create a sensitivity to spatial problems on a city-regional scale was eclipsed by antagonistic relations between public actors, resulting in turf battles. Other stakeholders mainly showed disinterest in the process and measures to restrain development outside of the urban growth boundaries were never implemented. Weak community input and the fact that citizens' self-interest did not 
coincide with the strategic spatial vision led to objections and disillusion, captured by local politics. The dissolution of the original vision is reflected in the discursive metamorphosis of the meaning of the phrase "safeguarding the future" from counteracting urban sprawl into safeguarding it by guaranteeing further development opportunities.

In the Antwerp case, the demarcation of the urban area never solidified into a stable policy arrangement for creating a metropolitan area and combatting urban sprawl on a city-regional scale. Instead, the substantive delineation of the problem, as reflected in the discourse of the Minister, shifted throughout the process from combatting sprawl to creating future development opportunities and solving a number of problematic spatial dossiers. The give-and-take between policy actors and interest groups was profoundly disturbed by strategic behaviour intended to safeguard individual interests. This left a focus on the 'rules of the game' according to which the demarcation process ought to take place. The foregrounding of these rules can be seen from the second stage of the process onward with a "procedural process" taking the place of strategic cooperation, a focus on meeting the quantitative targets for rezoning, the self-perception of the Committee of Spatial Planning as a "technical committee", and finally, in the lawsuits following the demarcation's approval. These findings show that the results of UGM instruments should not only be evaluated from the perspective of their measurable effectiveness, but as part of a project of institutional, discursive, and therefore, sociocultural change. Since a successor to the structure planning framework is currently in development [61], we can ask how a repetition of history may be prevented. The findings in this paper strongly suggest that future planning initiatives aimed at counteracting urban sprawl in Flanders need to take into account three elements. First, Flanders needs to free itself from the historical legacy of the Belgian land use planning system in order for new planning frameworks to have a chance at being successful. The legalistic focus on extensive land use rights established in a growth-centred era hamper any ambitious sustainable spatial development perspective for the region. ${ }^{16}$ Secondly, the historical animosity between cities and suburban fringe municipalities will not disappear if planning processes are merely centred on achieving quantitative targets and rely too much on the voluntary participation of these parties. Withdrawing the means for consultation or co-creative processes is a sure way of undermining any local support for city regional cooperation that might exist at the outset of a new planning initiative. Therefore, a strong planning vision and policy implementation on the Flemish regional level is needed to give direction to new initiatives for city-regional planning cooperation. The new Flemish "policy planning" framework is characterised by more elements of smart-growth strategies, including the active involvement of market parties and transferable development rights (TDR). Yet, it is our contention that these strategies will not work if the Flemish government does not adopt a directing role. In addition, political interlinkages between the local and the Flemish regional level need to be regarded with caution. They may aid to promote local support, but also carry the danger of too strong a representation of local interests on the regional level. Finally, public inquiry processes should not solely be treated as "technical coordination" of objections. Spatial planning in urban areas like these revolves around the distribution of scarce spatial resources, which implies that not every actor can be satisfied. However, more constructive ways of handling objections and creating public support need to be found if a new planning framework is to be successful.

Author Contributions: Conceptualization, C.d.O. and S.O.; methodology, C.d.O. and S.O.; formal analysis, C.d.O.; investigation, C.d.O.; data curation, C.d.O.; writing-original draft preparation, C.d.O.; writing-review and editing, C.d.O. and S.O.; visualization, C.d.O.; supervision, S.O.; project administration, C.d.O. Both authors have read and agreed to the published version of the manuscript.

Funding: This research received no external funding.

16 We are not alone in reaching this conclusion. Various Flemish planning experts argue for and propose ways of abolishing the national zoning plans $[62,63]$. 
Institutional Review Board Statement: Ethical review and approval were waived for this study as it did not meet the criteria of the risk analysis table provided by the Ethics Committee for the Social Sciences and Humanities of the University of Antwerp. The identities and contact details of the respondents are only known to the researchers and are not shared with other parties, no vulnerable parties were interviewed and no sensitive information was asked.

Informed Consent Statement: Informed consent was obtained from all subjects involved in the study.

Data Availability Statement: The data presented in this study are not publicly available due to the requirement to protect the participant identities. The data are available from the corresponding author only after the participants' consent.

Acknowledgments: The authors wish to thank all participants in the study for their insights, contributions and time.

Conflicts of Interest: The authors declare no conflict of interest.

\section{References}

1. Hack, G. Shaping Urban Form. In Planning Ideas That Matter; Sanyal, B., Vale, L., Rosan, C., Eds.; The MIT Press: Cambridge, MA, USA, 2012; pp. 33-64.

2. Bae, C.-H.C. Containing Sprawl. In Incentives, Regulations and Plans: The Role of States and Nation-states in Smart Growth Planning; Knaap, G.-J., Haccoû, H.A., Clifton, K.J., Frece, J.W., Eds.; Edward Elgar Publishing: Cheltenham, UK, 2007 ; pp. 36-53.

3. Chapin, T.S. Introduction: From Growth Controls, to Comprehensive Planning, to Smart Growth: Planning's Emerging Fourth Wave. J. Am. Plan. Assoc. 2012, 78, 5-15. [CrossRef]

4. Janssen-Jansen, L.B. Smart Growth Strategies as a Challenge for Dutch Developmental Planning Policies. In Incentives, Regulations and Plans: The Role of States and Nation-States in Smart Growth Planning; Knaap, G.J., Haccoû, H.A., Clifton, K.J., Frece, J.W., Eds.; Edward Elgar Publishing: Cheltenham, UK, 2007; pp. 233-252.

5. Calthorpe, P.; Fulton, W. The Regional City: Planning for the End of Sprawl; Island Press: Washington, DC, USA, 2001.

6. Knaap, G.J.; Nelson, A.C. The effects of regional land use control in Oregon: A theoretical and empirical review. Rev. Reg. Stud. 1988, 18, 37-46.

7. Cunningham, C.R. Growth Controls, Real Options, and Land Development. Rev. Econ. Stat. 2007, 89, 343-358. [CrossRef]

8. Pendall, R. Do land-use controls cause sprawl? Environ. Plan. B Plan. Des. 1999, 26, 555-571. [CrossRef]

9. Mathur, S. Impact of Urban Growth Boundary on Housing and Land Prices: Evidence from King County, Washington. Hous. Stud. 2014, 29, 128-148. [CrossRef]

10. Jaeger, W.K.; Plantinga, A.J.; Grout, C. How has Oregon's land use planning system affected property values? Land Use Policy 2012, 29, 62-72. [CrossRef]

11. Dawkins, C.J.; Nelson, A.C. Urban containment policies and housing prices: An international comparison with implications for future research. Land Use Policy 2002, 19, 1-12. [CrossRef]

12. Jun, M.-J. The Effects of Portland's Urban Growth Boundary on Urban Development Patterns and Commuting. Urban Stud. 2004, 41, 1333-1348. [CrossRef]

13. Wassmer, R.W. Fiscalisation of Land Use, Urban Growth Boundaries and Non-central Retail Sprawl in the Western United States. Urban Stud. 2002, 39, 1307-1327. [CrossRef]

14. Jun, M.-J. The effects of Seoul's greenbelt on the spatial distribution of population and employment, and on the real estate market. Ann. Reg. Sci. 2012, 49, 619-642. [CrossRef]

15. Dempsey, J.A.; Plantinga, A.J. How well do urban growth boundaries contain development? Results for Oregon using a difference-in-difference estimator. Reg. Sci. Urban Econ. 2013, 43, 996-1007. [CrossRef]

16. Gennaio, M.-P.; Hersperger, A.M.; Bürgi, M. Containing urban sprawl-Evaluating effectiveness of urban growth boundaries set by the Swiss Land Use Plan. Land Use Policy 2009, 26, 224-232. [CrossRef]

17. Anas, A.; Rhee, H.-J. When are urban growth boundaries not second-best policies to congestion tolls? J. Urban Econ. 2007, 61, 263-286. [CrossRef]

18. Brueckner, J.K. Urban growth boundaries: An effective second-best remedy for unpriced traffic congestion? J. Hous. Econ. 2007, 16, 263-273. [CrossRef]

19. Kline, J.D.; Thiers, P.R.; Ozawa, C.P.; Yeakley, J.A.; Gordon, S.N. How well has land-use planning worked under different governance regimes? A case study in the Portland, OR-Vancouver, WA metropolitan area, USA. Landsc. Urban Plan. 2014, 131, 51-63. [CrossRef]

20. Nelson, A.C.; Moore, T. Assessing growth management policy implementation. Land Use Policy 1996, 13, 241-259. [CrossRef]

21. Jann, W.; Wegrich, K. Theories of the Policy Cycle. In Handbook of Public Policy Analysis: Theory, Politics, and Methods; Fisher, F., Miller, G.J., Sidney, M.S., Eds.; CRC Press: Boca Raton, FL, USA, 2007; pp. 43-62.

22. Bengston, D.N.; Fletcher, J.O.; Nelson, K.C. Public policies for managing urban growth and protecting open space: Policy instruments and lessons learned in the United States. Landsc. Urban Plan. 2004, 69, 271-286. [CrossRef] 
23. Margerum, R.D. Evaluating Collaborative Planning: Implications from an Empirical Analysis of Growth Management. J. Am. Plan. Assoc. 2002, 68, 179-193. [CrossRef]

24. Margerum, R.D. Collaborative growth management in metropolitan Denver: "Fig leaf or valiant effort?". Land Use Policy 2005, 22, 373-386. [CrossRef]

25. Knaap, G.J. Self-Interest and Voter Support for Oregon's Land Use Controls. J. Am. Plan. Assoc. 1987, 53, 92-97. [CrossRef]

26. James, P.; Holden, M.; Lewin, M.; Neilson, L.; Oakley, C.; Truter, A.; Wilmoth, D. Managing metropolises by negotiating urban growth. In Institutional and Social Innovation for Sustainable Urban Development; Mieg, H., Töpfer, K., Eds.; Routledge: Abingdon, UK, 2013.

27. Van Tatenhove, J.; Arts, B.; Leroy, P. (Eds.) Political Modernisation and the Environment; Springer: Berlin/Heidelberg, Germany, 2000.

28. Arts, B.; Leroy, P. (Eds.) Institutional Dynamics in Environmental Governance. In Institutional Dynamics in Environmental Governance; Springer: Dordrecht, The Netherlands, 2006.

29. Liefferink, D. The Dynamics of Policy Arrangements: Turning Round the Tetrahedron. In Institutional Dynamics in Environmental Governance; Arts, B., Leroy, P., Eds.; Springer: Dordrecht, The Netherlands, 2006.

30. Van den Broeck, P.; Moulaert, F.; Kuhk, A.; Lievois, E.; Schreurs, J. Spatial planning in Flanders: Serving a bypassed capitalism? In Spatial Planning Systems and Practices in Europe; Reimer, M., Getimis, P., Blotevogel, H.H., Eds.; Routledge: London, UK; New York, NY, USA, 2014; pp. 169-188.

31. Vandevyvere, W. Van het Decreet van 18 mei 1999 houdende de Organisatie van de Ruimtelijke Ordening tot de Vlaamse Codex Ruimtelijke Ordening in 2009. In Handboek Ruimtelijke Ordening en Stedenbouw, 2nd ed.; Hubeau, B., Vandevyvere, W., Debersaques, G., Eds.; Die Keure: Brugge, Belgium, 2010.

32. Berisha, E.; Cotella, G.; Rivolin, U.J.; Solly, A. Spatial governance and planning systems in the public control of spatial development: A European typology. Eur. Plan. Stud. 2021, 29, 181-200. [CrossRef]

33. Poelmans, L.; Janssen, L.; Hambsch, L. Landgebruik en Ruimtebeslag in Vlaanderen, Toestand 2016; Study Executed on Behalf of the Flemish Planning Bureau for the Environment, Flemish Department of Environment: Brussels, Belgium, 2019.

34. Grietens, E. Vlaanderen in de Knoop: Een Uitweg Uit de Ruimtelijke Wanorde; Academic and Scientific Publishers: Brussel, Belgium, 2009.

35. Vermeiren, K.; Poelmans, L.; Engelen, G.; Broekx, S.; Beckx, C.; Nocker, L.D.; Dyck, K.V. Monetariseren van de Impact van Urban Sprawl in Vlaanderen; Study Executed on Behalf of the Flemish Department of Environment: Brussels, Belgium, 2019.

36. Meeus, B.; De Decker, P. De Geest van Suburbia; Garant: Antwerpen, Belgium, 2013.

37. Mustafa, A.; Teller, J. Self-Reinforcing Processes Governing Urban Sprawl in Belgium: Evidence over Six Decades. Sustainability 2020, 12, 4097. [CrossRef]

38. De Decker, P. Understanding Housing Sprawl: The Case of Flanders, Belgium. Environ. Plan. A Econ. Space 2011, 43, 1634-1654. [CrossRef]

39. Albrechts, L. Planners as catalysts and initiators of change. The new structure plan for Flanders. Eur. Plan. Stud. 1999, 7, 587-603. [CrossRef]

40. Vlaamse Overheid. Ruimtelijk Structuurplan Vlaanderen, Gecoördineerde Versie 2011; Departement Ruimtelijke Ordening Woonbeleid en Onroerend Erfgoed, Ed.; Flemish Government: Brussels, Belgium, 2011.

41. Leinfelder, H. 'Gevallen'-planning en hoe moeilijk het is om daden in gedachten te vertalen. In Ruimte Maken: Gebundelde Papers en Bijlagen PlanDag 2015; Bouma, G., Vanempten, E., Eds.; VRP/BNSP: Antwerpen, Belgium; Amsterdam, The Netherlands, 2015; pp. 133-142.

42. Voets, J.; De Peuter, B.; Vandekerckhove, B.; Broeckaert, D.; Le Roy, M.; Maes, P.; De Decker, P.; Bervoets, W.; Van der Heijden, R.; Blummel, P. Evaluerend Onderzoek naar de Effectiviteit van de Uitvoering van het Ruimtelijk Beleid in Vlaanderen; KU Leuven: Brussels, Belgium; SumResearch: Brussels, Belgium; Hogeschool voor Wetenschap en Kunst Sint-Lucas: Brussels, Belgium; Radboud Universiteit Nijmegen: Brussels, Belgium; Study executed on behalf of the Flemish Department of Spatial Planning, Housing Policy, and Heritage: Brussels, Belgium, 2010.

43. Boussauw, K.; Boelens, L. Fuzzy tales for hard blueprints: The selective coproduction of the Spatial Policy Plan for Flanders, Belgium. Environ. Plan. C Gov. Policy 2015, 33, 1376-1393. [CrossRef]

44. Cabus, P.; Rynck, F.D.; Voets, J.; Verhetsel, A.; Ackaert, J.; Miermans, W. Een Sterke Stad en Een Sterke Stadsregio: Verslag en Aanbevelingen op Basis Van Stadsregionale Gesprekken; Onderzoek Uitgevoerd in Opdracht van de Vlaams Minister van Binnenlands Bestuur, Stedenbeleid, Wonen en Inburgering: Brussel, Belgium, 2009.

45. Boucké, T. Samenspraak op Stadsregionaal Niveau: Verkennend en Inventariserend Onderzoek; Kenniscentrum Vlaamse Steden: Brussel, Belgium, 2015.

46. Vermeersch, C. Structuurplanning Vandaag: Oneigenlijk Gebruik en Misbruik; Published by the Author. Brugge, Belgium, 2008. Available online: https://nl.wikipedia.org/wiki/Charles_Vermeersch (accessed on 4 February 2021).

47. Boussauw, K.; Allaert, G.; Witlox, F. Colouring Inside What Lines? Interference of the Urban Growth Boundary and the Political-Administrative Border of Brussels. Eur. Plan. Stud. 2013, 21, 1509-1527. [CrossRef]

48. Informatie Vlaanderen. Bodembedekkingskaart (BBK), 1 m Resolutie, Opname 2015; Informatie Vlaanderen: Brussels, Belgium, 2015.

49. Vlaamse Overheid. Afbakeningen van de Stedelijke Gebieden in Uitvoering van het Ruimtelijk Structuurplan Vlaanderen-Toestand 2019; Vlaamse Overheid-Departement Omgeving: Brussel, Belgium, 2019. 
50. Vlaamse Overheid. Gewestelijk Ruimtelijk Uitvoeringsplan Afbakening Grootstedelijk Gebied Antwerpen; Ruimte Vlaanderen: Brussel, Belgium, 2009.

51. Vlacoro. Advies Ontwerp Gewestelijk Ruimtelijk Uitvoeringsplan: Afbakening Grootstedelijk Gebied Antwerpen; Flemish Committee for Spatial Planning: Brussels, Belgium, 2009.

52. Voets, J.; Peuter, B.D.; Rynck, F.D.; Herck, B.V.; Laat, W.D.; Vloebergh, G.; Broeck, P.V.D. Onderzoek Naar de Voor het Vlaams Ruimtelijk Beleid Relevante Vormen van Intergemeentelijke Samenwerking; Instituut voor de Overheid—KU Leuven: Brussels, Belgium; Departement HABE, Hogeschool Gent: Brussels, Belgium; IDEA Consult: Brussels, Belgium; OMGEVING: Brussels, Belgium; Study executed on behalf of the Flemish Department of Spatial Planning, Housing Policy, and Heritage: Brussels, Belgium, 2012.

53. Coppens, T.; Van Den Broeck, J.; Van Wymeersch, E. Een Evaluatie van Subsidies Voor de Projectcoordinatie van Strategische Projecten in Turnhout en Aalst; Study Executed on Behalf of the Flemish Department of Environment: Brussels, Belgium, 2016.

54. Van Baelen, J. Plaats om te Bouwen; Gazet van Antwerpen: Antwerpen, Belgium, 2009.

55. Omgeving. Methode voor de Afbakening van Stedelijke Gebieden; Studiegroep Omgeving: Antwerpen, Belgium, 1996.

56. Studiegroep Omgeving \& Buck Consultants International. Voorontwerp Afbakening Grootstedelijk Gebied Antwerpen; Study Executed on Behalf of the AROHM Ministry of the Flemish Community: Brussels, Belgium, 2005.

57. Van den Broeck, J.; Vermeulen, P.; Oosterlynck, S.; Albeda, Y. Antwerpen Herwonnen Stad? Maatschappij, Ruimtelijk Plannen en Beleid. 1940-2012; Die Keure: Brugge, Belgium, 2014.

58. De Olde, C.; Oosterlynck, S. "The countryside starts here": How the urban-rural divide continues to matter in post-urban Flanders. 2021, Manuscript submitted for publication.

59. Broeck, P.V.D.; Verachtert, K. Whose Permits? The Tenacity of Permissive Development Control in Flanders. Eur. Plan. Stud. 2015, 24, 387-406. [CrossRef]

60. Fairclough, N. Analysing Discourse: Textual Analysis for Social Research; Routledge: London, UK, 2003.

61. Departement Omgeving Vlaanderen. Strategische Visie Beleidsplan Ruimte Vlaanderen; Flemish Department of Environment: Brussels, Belgium, 2018.

62. De Olde, C.; Boussauw, K.; Ryckewaert, M. Draagvlak voor de Betonstop Groter Maken? Vlaamse Overheid Vergroot Enkel een Vastgoedzeepbel; Knack: Brussels, Belgium, 2020. Available online: https://www.knack.be/nieuws/belgie/draagvlak-voor-debetonstop-groter-maken-vlaamse-overheid-vergroot-enkel-een-vastgoedzeepbel/article-opinion-1677389.html (accessed on 3 February 2021).

63. Coppens, T.; Vloebergh, G.; De Decker, P.; Leinfelder, H. Hoe Kunnen we het Gewestplan Afschaffen? Ruimte 2020, 47, $24-29$. 